Western North American Naturalist 69(3), ( 2009, pp. 351-363

\title{
RELATIVE AND SEASONAL ABUNDANCE OF THREE BARK BEETLE PREDATORS (COLEOPTERA: TROGOSITIDAE, CLERIDAE) ACROSS AN ELEVATION GRADIENT IN PONDEROSA PINE FORESTS OF NORTH CENTRAL ARIZONA
}

\author{
Kelly K. Williams ${ }^{1}$, Joel D. McMillin², and Tom E. DeGomez ${ }^{1}$
}

\begin{abstract}
Aвstract-We examined abundance and flight periodicity of 3 predators of bark beetles (Coleoptera: Curculionidae, Scolytinae), Temnochila chlorodia (Mannerheim) (Coleoptera: Trogositidae), Enoclerus sphegeus (Fabricius) (Coleoptera: Cleridae), and E. lecontei (Wolcott) (Coleoptera: Cleridae), across an elevational gradient of ponderosa pine (Pinus ponderosa Lawson) forests in north central Arizona. Predator populations were estimated at 10 sites in each of 3 elevation bands (low: 1600-1736 m; mid: 2058-2230 m; high: 2505-2651 m) for 3 years (2004-2006) using pheromone-baited funnel traps targeting 3 primary bark beetle species. We also investigated how predator abundance and flight seasonality related to those of 5 bark beetle species: Ips pini (Say), I. lecontei Swaine, Dendroctomus frontalis Zimmermann, D. brevicomis LeConte, and D. adjunctus Blandford. Temnochila chlorodia was most abundant in the low- and mid-elevation bands, whereas E. sphegeus was most abundant in the high-elevation band. Enoclerus lecontei showed no consistent elevational trend in abundance. Within each elevation band, changes in annual abundance of pooled predator species tracked shifts in abundance of pooled bark beetle species. In general, predator flight initiation coincided with or closely followed bark beetle flight initiation in the spring, but predator flight terminated before flight activity ended for most bark beetle species in the fall. In addition, the ratio of prey to predators was lowest in the summer and highest in the fall. This suggests that all bark beetle species examined may be provided temporal escape from their predators in the fall. For all 3 predator species, the pheromone-baited trap targeting $D$. brevicomis was less attractive than the pheromone-baited traps targeting I. pini and I. lecontei.
\end{abstract}

Key words: predators, bark beetles, abundance, elevation, flight seasonality, ponderosa pine, Enoclerus lecontei, Enoclerus sphegeus, Temnochila chlorodia, Dendroctonus, Ips.

Bark beetles (Coleoptera: Curculionidae, Scolytinae) cause significant pine mortality in the western United States (Furniss and Carolin 1977). Recently, bark beetles, drought, and forest conditions interacted to cause unprecedented levels of ponderosa pine (Pinus ponderosa Lawson) mortality throughout Arizona (USDA Forest Service 2003-2004). The bark beetle community in Arizona's ponderosa pine forests is complex, comprising several primary (i.e., capable of attacking, colonizing, and killing apparently healthy trees) and secondary (i.e., infesting weakened, dead, or dying trees) species. Primary species of concern in Arizona's ponderosa pine forests include Ips pini (Say), I. lecontei Swaine, Dendroctonus frontalis Zimmermann, D. brevicomis LeConte, and $D$. adjunctus Blandford (Dahms and Geils 1997, USDA Forest Service 2003-2004, Williams et al. 2008). All 5 species are found throughout the elevational range of ponderosa pine in north central Arizona; however, their abundance and periods of flight activity vary across elevation (Hayes et al. 2008, Williams et al. 2008).

Natural enemies (predators, parasites, pathogens) can play a role in regulating bark beetle population dynamics (Reeve 1997, Turchin et al. 1999, Gara et al. 1999, Erbilgin et al. 2002, Reeve and Turchin 2002). Coleopteran predators of bark beetles are considered "habitat specialists" because they feed exclusively within trees colonized by bark beetles, but they are also referred to as "feeding generalists" because they prey on several Scolytinae that inhabit the same tree (Erbilgin and Raffa 2001). Three bark beetle predators commonly found in ponderosa pine forests of north central Arizona are Temnochila chlorodia (Mannerheim) (Coleoptera: Trogositidae), Enoclerus sphegeus (Fabricius) (Coleoptera: Cleridae), and E. lecontei (Wolcott) (Coleoptera: Cleridae) (Blackman 1931, Ostmark 1966, Sánchez-Martínez and

${ }^{1}$ University of Arizona, School of Natural Resources, NAU Box 15018, Flagstaff, AZ 86011

${ }^{2}$ Corresponding author. USDA Forest Service, Southwestern Region, Forestry and Forest Health, Arizona Zone, 2500 S. Pine Knoll Drive, Flagstaff, AZ 86001. E-mail: jmcmillin@fs.fed.us 
Wagner 2002, Gaylord et al. 2006). The larval and adult stages of all 3 predators are known to be predaceous on the larval and adult stages of their bark beetle prey (Blackman 1931, Struble 1942, Miller and Keen 1960, Ostmark 1966, Berryman 1970, Furniss and Carolin 1977). All 3 species are known predators of several primary Dendroctomus and Ips species in the western U.S. (Blackman 1931, Person 1940, Ostmark 1966, Chansler 1967, Berryman 1970, Stephen and Dahlsten 1976, Massey et al. 1977, Bedard et al. 1980, DeMars and Roettgering 1982, Raffa and Dahlsten 1995, Gara et al. 1999, Aukema et al. 2000a, 2000b, Dahlsten et al. 2003, 2004).

Predators exploit bark beetle pheromones as kairomones to locate their prey (Wood 1982) and therefore are attracted to funnel traps baited with semiochemical lures. Pheromonebaited traps have been used to describe and compare the seasonal distributions of bark beetles with those of their predators, including I. pini with several predators in California (Dahlsten et al. 2003, 2004) and Wisconsin (Raffa 1991, Aukema et al. 2000a, 2000b, Erbilgin et al. 2002, Aukema et al. 2005); I. pini with T. chlorodia, E. sphegeus, and E. lecontei in Montana (Gara et al. 1999); and D. brevicomis with T. chlorodia in California (Fettig and Dabney 2006). Temnochila chlorodia is attracted to exo-brevicomin (Pitman and Vité 1971, Bedard et al. 1980, Byers 1988, Zhou et al. 2001, Hofstetter et al. 2008) and ipsdienol (Seybold et al. 1992, Miller et al. 1997, Dahlsten et al. 2003, 2004). Enoclerus sphegeus is attracted to ipsdienol (Miller and Borden 1990, Seybold et al. 1992, Miller et al. 1997, Dahlsten et al. 2004) and a combination of ipsenol and cis-verbenol (Miller et al. 1991). Enoclerus lecontei is attracted to ipsenol (Wood et al. 1968) and ipsdienol, especially when enhanced with the addition of lanierone in western North America (Seybold et al. 1992, Miller et al. 1997, Dahlsten et al. 2003, 2004, Miller et al. 2005). In a recent study on lure preferences of bark beetles and their predators near Flagstaff, Arizona (Gaylord et al. 2006), T. chlorodia and Enoclerus species were most attracted to the lure targeted for I. pini (ipsdienol +03/-97 and lanierone). Seasonal flight patterns of $T$. chlorodia and Enoclerus species were also examined by Gaylord et al. (2006). However, it is unknown how predator abundance and flight seasonality vary across the broader elevational range of ponderosa pine in the Southwest.
The primary objective of this study was to describe the relative and seasonal abundance of 3 bark beetle predators-T. chlorodia, $E$. sphegeus, and E. lecontei-across an elevational gradient in north central Arizona's ponderosa pine forests. Abundance and flight periodicity were determined using pheromonebaited funnel traps (Lindgren 1983). In addition, we discuss these results in relation to the abundance and flight seasonality of 5 bark beetle species (I. pini, I. lecontei, D. frontalis, $D$. brevicomis, and D. adjunctus) recently investigated by Williams et al. (2008). Secondary objectives of this study included (1) comparing changes in annual abundance of pooled predator species with dynamics of pooled bark beetle species and (2) determining which bark beetle pheromone lure was preferred by each predator.

\section{Methods}

\section{Study Site}

Study sites were located in stands of ponderosa pine on the Coconino, Kaibab, and Tonto National Forests in north central Arizona (Fig. 1). All sites were located in the interior-ponderosa-pine cover type as described by the Society of American Foresters (Eyre 1980). Xerophytic forests at low elevations $(1600-1736 \mathrm{~m})$ were bordered by pinyonjuniper woodlands and included trees and shrubs such as pinyon pine (Pinus edulis Engelm.), alligator juniper (Juniperus deppeana Steud.), Utah juniper (J. osteosperma [Torr.] Little), Arizona white oak (Quercus arizonica Sarg.), manzanita (Arctostaphylos pungens Kunth), and yuccas (Yucca spp.; Moir et al. 1997, USDA Forest Service 2002a). Midelevation xerophytic forests $(2058-2230 \mathrm{~m})$ were dominated by ponderosa pine. Understory vegetation at mid-elevations ranged from bunchgrasses to one-seed juniper (J. monosperma [Engelm.] Starg.) and Gambel oak (Q. gambelii Nutt.) (Moir et al. 1997, USDA Forest Service $2002 \mathrm{~b})$. In the high-elevation band (2505-2651 $\mathrm{m})$, ponderosa pine stands were intermingled with mixed conifer stands, and sites were located in both xerophytic and mesophytic forest zones (Moir et al. 1997). Additional tree species found at high-elevation sites included Douglas-fir (Pseudotsuga menziesii [Mirb.] Franco), limber pine (Pinus flexilis James), white fir (Abies concolor [Gord. \& Glend.] 


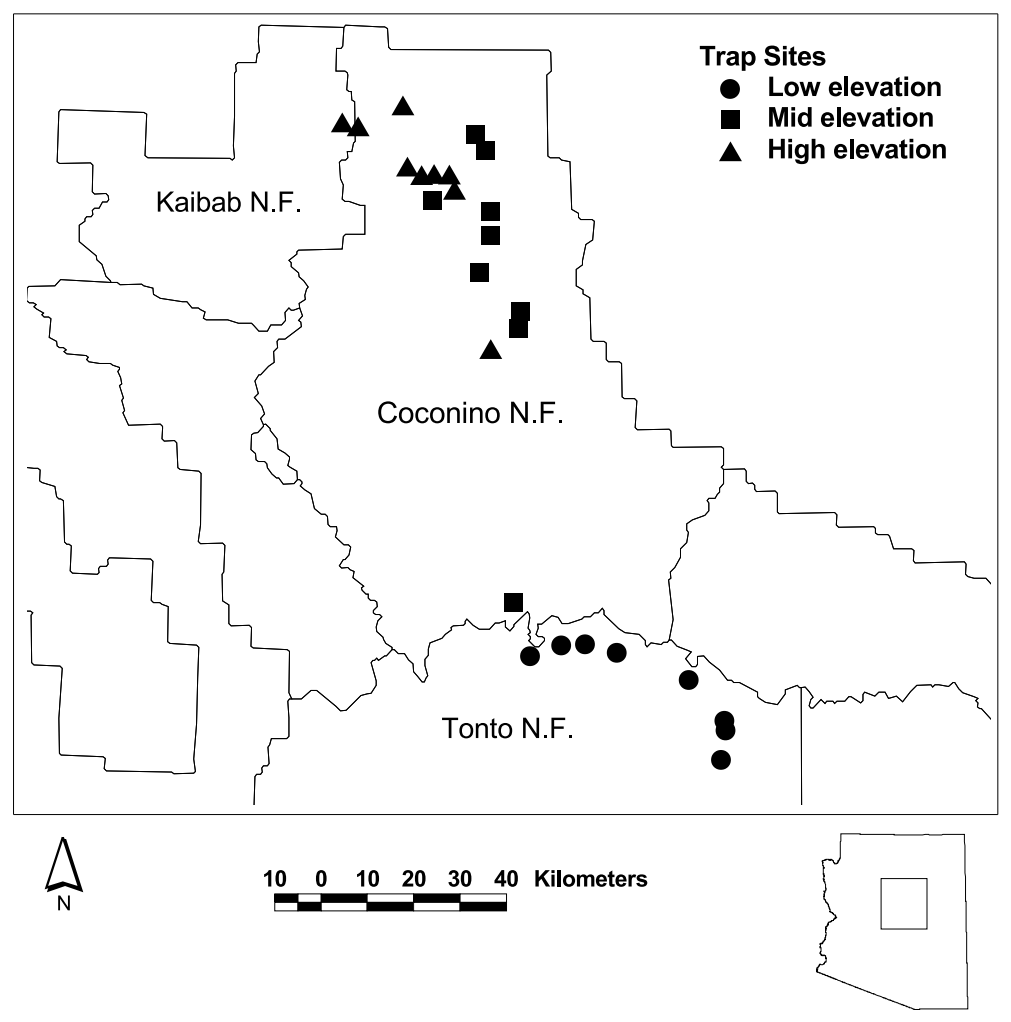

Fig. 1. Map showing the location of low- (1600-1736 m), mid- (2058-2230 m) and high- (2505-2651 m) elevation sites used in all 3 years of study for trapping bark beetles and their predators in ponderosa pine forests of north central Arizona, 2004-2006

Lindl. ex Hildebr. var. concolor), and quaking aspen (Populus tremuloides Michx.) (Moir et al. 1997, USDA Forest Service 2002b, 2002c).

\section{Study Design}

Ten sites were established in each of 3 elevation bands: low (1600-1736 m), mid (2058-2230 m), and high (2505-2651 m). Sites within an elevation band were separated by a minimum of $2 \mathrm{~km}$. Sites were within $100 \mathrm{~m}$ of the edge of ponderosa pine stands and within 50 to $200 \mathrm{~m}$ of forest roads to facilitate collection of traps. Efforts were made to maintain the same trapping locations each year; however, forest management activities and forest road closures required the removal of one low-elevation site and one high-elevation site and the relocation of one low-elevation site and one mid-elevation site. Relocated sites were within $9 \mathrm{~km}$ of the original sites.

Each site contained three 12-unit Lindgren funnel traps (Lindgren 1983, Pherotech
International Inc., Delta, BC, Canada) arranged in an approximately 15-m equilateral triangle. Traps were suspended from 3-m aluminum conduit poles, with the bottoms of traps about $1 \mathrm{~m}$ from the ground. Traps were baited with commercially-available lures for I. pini, I. lecontei, and D. brevicomis (Table 1). These lure combinations were also expected to capture other bark beetle species and their coleopteran predators, based on a previous study in northern Arizona (Gaylord et al. 2006). Lures were replaced every 7 weeks to ensure adequate pheromone elution rates. Traps were also moved within the triangle on a regular basis to minimize location impacts. A $2.5 \times 2.5-\mathrm{cm}$ square of Spectracide Bug Stop ${ }^{\circledR}$ pest strip (18.6\% Dichlorvos, United Industries Corp., St. Louis, MO) was placed in each collection cup to kill trapped insects and minimize predation by invertebrates.

The length of the trapping season varied across elevation and year (Table 2) and was 
TABLE 1. Description of semiochemical lures (Pherotech International Inc., Delta, British Columbia, Canada) used in Lindgren funnel traps located in 3 elevation bands in the Coconino, Kaibab, and Tonto National Forests, Arizona, 2004-2006.

\begin{tabular}{|c|c|c|c|}
\hline Bark beetle species & Semiochemical lure & Chemical purity $(\%)$ & Release rate $\left(\mathrm{mg} \cdot 24 \mathrm{~h}^{-1}\right)$ \\
\hline Ips pini & $\begin{array}{c}\text { Ipsdienol +03/-97 } \\
\text { Lanierone }\end{array}$ & $\begin{array}{l}>95 \\
>97\end{array}$ & $\begin{array}{l}0.2 @ 25{ }^{\circ} \mathrm{C} \\
0.009 @ 25{ }^{\circ} \mathrm{C}\end{array}$ \\
\hline Ips lecontei & $\begin{array}{c}\text { Ipsdienol }+50 /-50 \\
\text { Ispsenol }+50 /-50 \\
\text { Cis-verbenol }+17 /-83\end{array}$ & $\begin{array}{l}>95 \\
>96 \\
>90\end{array}$ & $\begin{array}{l}0.2 @ 25^{\circ} \mathrm{C} \\
0.4 @ 25^{\circ} \mathrm{C} \\
0.6 @ 20^{\circ} \mathrm{C}\end{array}$ \\
\hline Dendroctonus brevicomis & $\begin{array}{c}\text { Frontalin } \\
\text { Exo-brevicomin } \\
\text { Myrcene (X2) }\end{array}$ & $\begin{array}{l}>99 \\
>99 \\
>90\end{array}$ & $\begin{array}{l}2.6 @ 23{ }^{\circ} \mathrm{C} \\
1.7 @ 23{ }^{\circ} \mathrm{C} \\
6.5 @ 23{ }^{\circ} \mathrm{C}\end{array}$ \\
\hline
\end{tabular}

TABLE 2. Dates of sampling bark beetle and associatedpredator flight in ponderosa pine forests on the Coconino, Kaibab, and Tonto National Forests, Arizona, at 3 elevations: low (1600-1736 m), mid (2058-2230 m), and high (2505-2651 m), 2004-2006.

\begin{tabular}{lccc}
\hline & \multicolumn{3}{c}{ Elevation band } \\
\cline { 2 - 4 } Year & Low & Mid & High \\
\hline 2004 & 12 Apr-16 Nov & 13 Apr-15 Nov & 28 Apr-15 Nov \\
2005 & 8 Mar-6 Dec & 23 Mar-8 Dec & 25 Apr-28 Nov \\
2006 & 7 Mar-12 Dec & 9 Mar-7 Dec & 27 Mar-6 Dec \\
\hline
\end{tabular}

initially based on the results of a recent study near Flagstaff, Arizona (Gaylord et al. 2006). Initiation and cessation of trapping at highelevation sites in all years depended on site accessibility due to spring and fall weather. Based on 2004 data, efforts were made in 2005 and 2006 to extend the length of the trapping seasons for all elevations so that trap-catch data would start and end with zero trap catches, reflecting a true initiation and cessation of flight activity for all species.

Contents of traps were collected approximately once per week. Bark beetles and predators were identified to species each year except in 2004, when Enoclerus beetles were only identified to genus. Voucher specimens are maintained at the Rocky Mountain Research Station, USDA Forest Service, Flagstaff, Arizona.

\section{Statistical Analysis}

With the exception of the lure comparison analysis, beetle count was summed across all 3 traps for each site and collection period because all 3 species of predators were caught in each of the different pheromone-baited traps. Although most trap collection periods were 1 week, collection periods ranged from 4 to 17 days. To standardize data, total trap catch per site for a collection period was divided by the number of days in that collection period and multiplied by 7 to give a value representing total trap catch for a week (Williams et al. 2008). Average weekly beetle capture for a trapping season was calculated for each site using data from collection weeks when at least one trap was deployed in each elevation band.

Multiple response permutation procedure (MRPP) (Mielke and Berry 2001) for one-factor designs (macros developed by Rudy King, Rocky Mountain Research Station Statistics Unit, USDA Forest Service) was used for multiple comparison of means. MRPP, a nonparametric technique, can be used as an alternative to multivariate analysis of variance (MANOVA). MRPP does not require normal distribution and equal variance of data (Mielke and Berry 2001) because the hypothesis testing only depends on the internal variability of the sample (SánchezMartínez and Wagner 2002). The $P$ value is calculated using a permutation procedure that involves all possible arrangements of the $N$ observations to the different treatments, under the null hypothesis that all permutations have the same probability of occurrence (Zimmerman et al. 2005). All tests were run with a significance level of $\alpha=0.05$. MRPP was used to assess elevational trends in predator abundance, relative abundance of predators within each elevation band, and lure preferences of predators. Seasonal and annual changes in prey-predator ratios were also analyzed with MRPP using the prey data presented in the Williams et al. study (2008). When analysis included predators pooled across all species, all 3 years of data were used. When analysis involved individual predator species, 2004 data were omitted because the Enoclerus genus was not identified to species.

Graphs that plot the mean weekly trap catch per site against time (pooled years: 2005-2006) for individual predator species were generated 
TABLE 3. $P$ values for multiple response permutation procedure (MRPP) testing for differences in bark beetle predator abundance among low- (1600-1736 m), mid- (2058-2230 m), and high- (2505-2651 m) elevation bands in north central Arizona. $\mathrm{L}=$ low-elevation band, $\mathrm{M}=$ mid-elevation band, $\mathrm{H}=$ high-elevation band.

\begin{tabular}{|c|c|c|c|c|c|c|}
\hline \multirow[b]{2}{*}{ Predator species } & \multirow[b]{2}{*}{ Year } & \multicolumn{4}{|c|}{$P$ value } & \multirow[b]{2}{*}{ Trend } \\
\hline & & All bands ${ }^{a}$ & L vs. M & L vs. H & M vs. H & \\
\hline Temnochila chlorodia & $\begin{array}{l}2004 \\
2005 \\
2006\end{array}$ & $\begin{array}{r}0.005 \\
<0.001 \\
<0.001\end{array}$ & $\begin{array}{r}0.031 \\
<0.001 \\
0.010\end{array}$ & $\begin{array}{r}0.439 \\
0.006 \\
<0.001\end{array}$ & $\begin{array}{l}0.003 \\
0.522 \\
0.144\end{array}$ & $\begin{array}{l}M>L \& H \\
L>M \& H \\
L>M \& H\end{array}$ \\
\hline Enoclerus sphegeus & $\begin{array}{l}2005 \\
2006\end{array}$ & $\begin{array}{l}<0.001 \\
<0.001\end{array}$ & $\begin{array}{l}0.010 \\
0.001\end{array}$ & $\begin{array}{l}<0.001 \\
<0.001\end{array}$ & $\begin{array}{l}<0.001 \\
<0.001\end{array}$ & $\begin{array}{l}\mathrm{H}>\mathrm{M}>\mathrm{L} \\
\mathrm{H}>\mathrm{M}>\mathrm{L}\end{array}$ \\
\hline Enoclerus lecontei & $\begin{array}{l}2005 \\
2006^{\mathrm{b}}\end{array}$ & $\begin{array}{r}<0.001 \\
0.150\end{array}$ & $\begin{array}{c}0.006 \\
-\end{array}$ & $\begin{array}{c}0.001 \\
-\end{array}$ & $\begin{array}{c}0.088 \\
-\end{array}$ & $\begin{array}{c}\mathrm{L}>\mathrm{M} \& \mathrm{H} \\
-\end{array}$ \\
\hline
\end{tabular}

$\mathrm{H}_{\mathrm{o}}$ : Low-, mid- and high-elevation means are similar:

Pairwise comparisons are not shown for $E$. lecontei in 2006 because overall test was not significant.

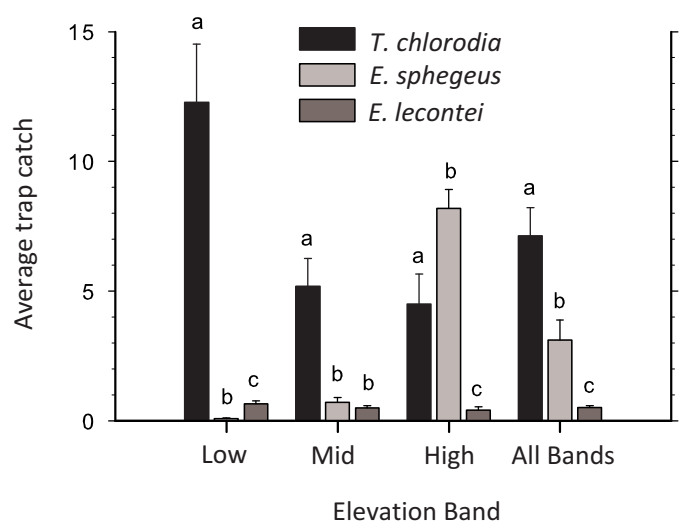

Fig. 2. Relative abundance of 3 bark beetle predators collected in funnel traps in low- (1600-1736 m), mid(2058-2230 m), and high- (2505-2651 m) elevation bands, and in all elevations bands pooled, in north central Arizona, 2005-2006. Data are presented as mean weekly trap catch per site pooled by years. Error bars represent one standard error. Means followed by the same letter within an elevation band are not significantly different $(P>0.05$, MRPP).

to supplement the MRPP analysis. These graphs provided insight into peak captures and initiation and cessation of flight activity. Additionally, trap catches of 5 bark beetle species (I. pini, I. lecontei, D. frontalis, D. brevicomis, and D. adjunctus) examined in Williams et al. (2008) were included in the temporal graphs to facilitate comparisons of seasonal flight patterns between bark beetles and their predators.

\section{RESULTS}

\section{Predator Abundance}

The 3 predator species examined in this study exhibited different trends in intraspecies abundance among elevations (Table 3). Temnochila chlorodia showed a trend of higher abundance at low-elevation (2005 and 2006) or mid-elevation sites (2004; Table 3). Enoclerus sphegeus displayed the opposite trend, with abundance being highest in the high-elevation band in both 2005 and 2006 (Table 3). No obvious trend in abundance was found for $E$. lecontei; abundance was highest in the lowelevation band in 2005 but did not vary by elevation in 2006 (Table 3 ).

Relative interspecies abundance of the 3 predators varied among elevation bands for the 2 trapping seasons (2005 and 2006) in which Enoclerus individuals were identified to species (Fig. 2). At low-elevation sites, T. chlorodia was the most common predator collected $(P<0.001)$ and represented $94.2 \%$ of the 8311 predators collected, followed by E. lecontei $(5.2 \%)$ and E. sphegeus $(0.5 \%)$. At mid-elevation sites, $T$. chlorodia was again the most abundant predator $(P<0.001)$ and represented $78.5 \%$ of the 3756 predators captured; E. sphegeus $(13.0 \%)$ and E. lecontei (8.5\%) were found in lower numbers. At high-elevation sites, $E$. sphegeus was the most abundant predator $(P<$ 0.001 ) and accounted for $62.5 \%$ of the 6037 predators captured, followed by $T$. chlorodia $(34.4 \%)$ and E. lecontei (3.0\%). Across all elevations, $T$. chlorodia was the most common predator collected $(P<0.005)$, accounting for $71.0 \%$ of the 18,104 predators captured, followed by E. sphegeus (23.8\%) and E. lecontei $(5.2 \%)$.

\section{Flight Seasonality}

Flight activity of $T$. chlorodia varied across elevation (Fig. 3). Flight initiated as early as mid-March and terminated as late as midNovember in the low-elevation band; flight 


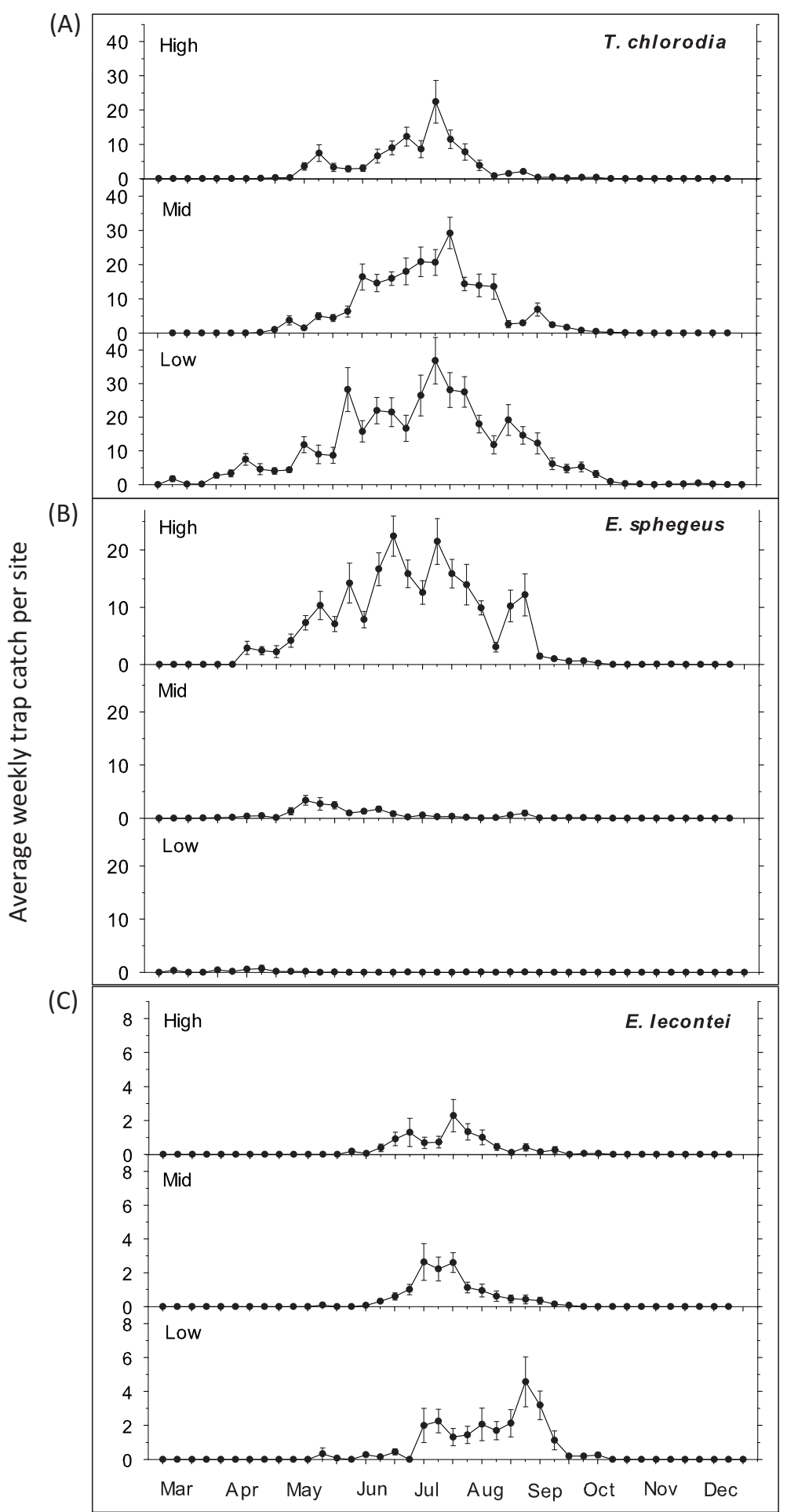

Fig. 3. Seasonal beetle captures of T. chlorodia, E. sphegeus, and E. lecontei at low- (1600-1736 m), mid- (2058-2230 $\mathrm{m})$ and high- $(2505-2651 \mathrm{~m})$ elevation bands in ponderosa pine forests of north central Arizona, 2005-2006. Error bars represent one standard error. 


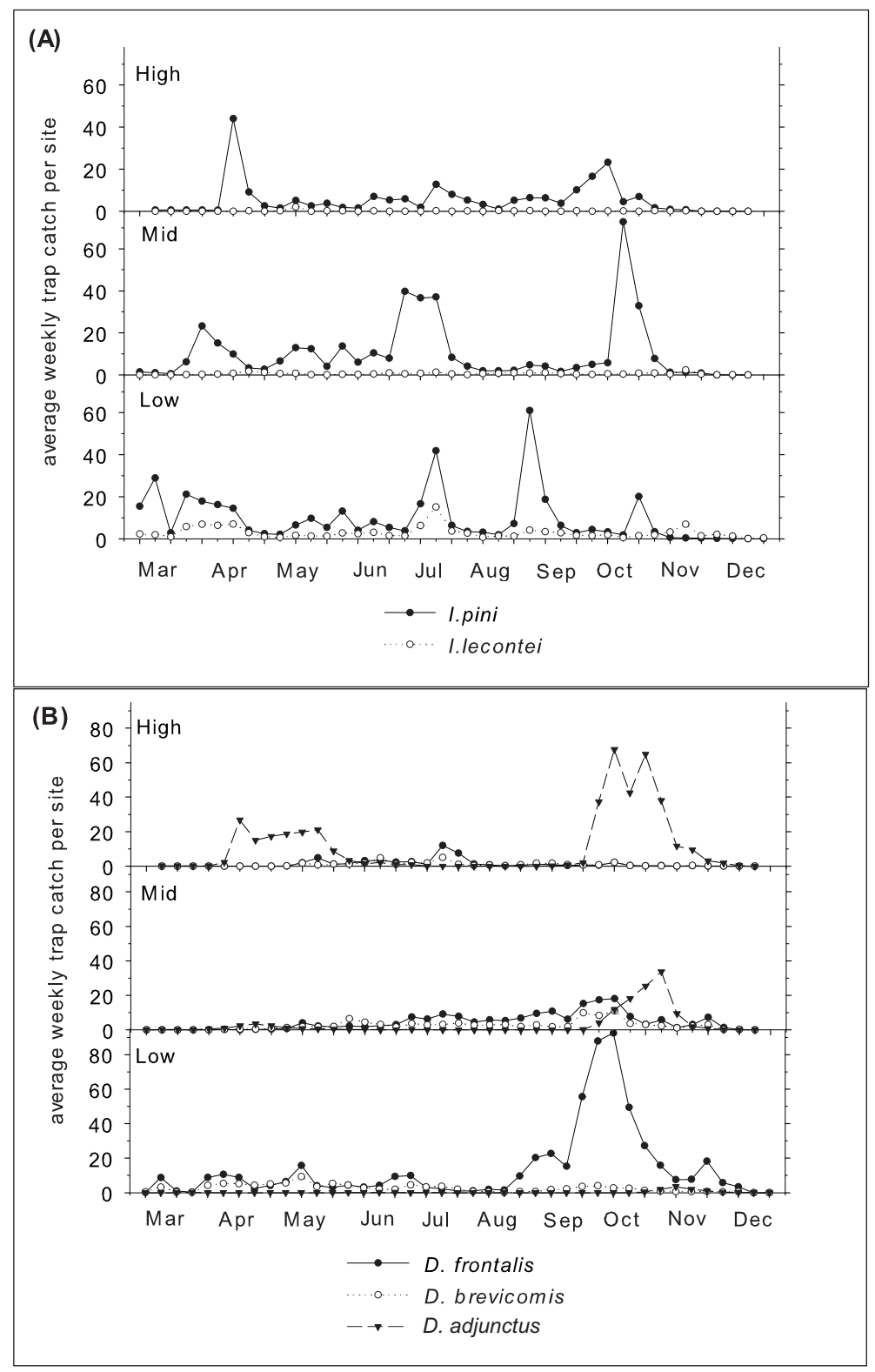

Fig. 4. Seasonal beetle captures of (A) I. pini and I. lecontei and (B) D. frontalis, D. brevicomis, and D. adjunctus at low- (1600-1736 m), mid- (2058-2230 m) and high- (2505-2651 m) elevation bands in ponderosa pine forests of north central Arizona, 2004-2006.

initiation was delayed at least one month in the mid- and high-elevation bands. Flight initiation coincided with or shortly followed spring flight initiation of several bark beetle species. At all elevations, T. chlorodia trap catches peaked by late July. Flight activity ended at least one month later in the low- and mid-elevation bands than in the high-elevation band.
While high trap catches of T. chlorodia coincided with peak summer flight activity of $I$. pini and I. lecontei at low elevations, its abundance was much lower during spring and fall peaks of these 2 bark beetle species (Fig. 4a). Across all elevations, flight activity of T. chlorodia overlapped spring and summer flight activity of $D$. brevicomis and $D$. frontalis but 
TABLE 4. Mean prey: predator ratios $\left(s_{\bar{x}}\right)$ for the spring (March-May), summer (June-August), and fall (September-November) trapping periods for low- (1600-1736 m), mid- (2058-2230 m) and high- (2505-2651 m) elevation bands in north central Arizona. Ratios are developed from mean weekly trap catch data per site pooled by years (2004-2006). Prey include I. pini, I. lecontei, D. frontalis, D. brevicomis, and D. adjunctus. Predators include T. chlorodia, E. sphegeus, and E. lecontei. Means followed by the same letter within an elevation band are not significantly different $(P>0.05, \mathrm{MRPP})$.

\begin{tabular}{llcc}
\hline $\begin{array}{l}\text { Elevation } \\
\text { band }\end{array}$ & \multicolumn{1}{c}{ Spring } & Summer & Fall \\
\hline Low & $4.66(0.79) \mathrm{a}$ & $1.05(0.10) \mathrm{b}$ & $15.25(2.88) \mathrm{c}$ \\
Mid & $4.97(0.786) \mathrm{a}$ & $1.73(0.21) \mathrm{b}$ & $62.62(9.53) \mathrm{c}$ \\
High & $4.86(0.93) \mathrm{a}$ & $0.56(0.07) \mathrm{b}$ & $50.63(9.12) \mathrm{c}$ \\
\hline
\end{tabular}

TABLE 5. Mean prey:predator ratios $\left(s_{\bar{x}}\right)$ during 2004-2006 trapping periods for low- (1600-1736 m), mid(2058-2230 m), and high- (2505-2651 m) elevation bands in north central Arizona. Ratios are developed from mean weekly trap catch data per site. Prey include I. pini, I. lecontei, D. frontalis, D. brevicomis, and D. adjunctus. Predators include T. chlorodia, E. sphegeus, and E. lecontei. Means followed by the same letter within an elevation band are not significantly different $(P>0.05$, MRPP).

\begin{tabular}{lccc}
\hline $\begin{array}{l}\text { Elevation } \\
\text { band }\end{array}$ & 2004 & 2005 & 2006 \\
\hline Low & $4.37(5.18) \mathrm{a}$ & $2.71(2.16) \mathrm{a}$ & $2.14(0.90) \mathrm{a}$ \\
Mid & $2.00(1.16) \mathrm{a}$ & $5.26(2.55) \mathrm{b}$ & $5.72(2.71) \mathrm{b}$ \\
High & $1.82(1.10) \mathrm{a}$ & $2.00(1.68) \mathrm{a}$ & $2.36(1.30) \mathrm{a}$ \\
All bands & $2.67(3.11) \mathrm{a}$ & $2.35(2.53) \mathrm{a}$ & $3.46(2.44) \mathrm{a}$ \\
\hline
\end{tabular}

diminished before bark beetle flight terminated in the fall (Fig. 4b).

Flight activity of E. sphegeus varied across elevations, with flight initiation and termination occurring 2-4 weeks earlier for each decrease in elevational band (Fig. 3). At highelevation sites, flight initiation coincided with spring flight initiation of $D$. adjunctus (Fig. $4 \mathrm{~b}$ ). Trap catches were highest in June and July and corresponded with summer flight activity of I. pini, D. brevicomis, and D. frontalis (Fig. 4). Trap catches declined before fall peaks in flight activity of I. pini and D. adjunctus in the high-elevation band. At low- and mid-elevation sites, the highest catches of $E$. sphegeus occurred in April (low-elevation band) and May (mid-elevation band). Trap catches during these months accounted for $78.1 \%$ of the 534 beetles caught.

Flight activity of E. lecontei did not vary greatly across elevation, with beetles caught mostly from May to October in all elevation bands (Fig. 3). Flight initiated in the spring after bark beetle flight had already begun (Fig. 4). The majority of flight activity across the elevation bands occurred from early July to early September; trap catches during this period accounted for $88.4 \%$ of the 940 total beetles captured. High trap catches in July and August corresponded with peak flights of I. pini and I. lecontei (low-elevation band only) and overlapped summer flight activity of $D$. brevicomis and $D$. frontalis. Flight activity of E. lecontei decreased before peak bark beetle flight activity occurred in the fall.

The ratio of prey (I. pini, I. lecontei, D. frontalis, D. brevicomis, and D. adjunctus) to predators (T. chlorodia, E. sphegeus, and E. lecontei) varied throughout the year (Table 4). The ratio was highest in the fall (Sep.-Nov.) and lowest during the summer months (Jun.-Aug.) in all 3 elevation bands. Overall, predator flight initiation coincided with or shortly followed bark beetle flight initiation in the spring, while predator flight activity tapered off in the fall before bark beetle flight activity ended (Figs. $3,4)$. During the fall months, traps captured anywhere from 15 (low-elevation band) to 62 (mid-elevation band) times more prey than predators $(P<0.001)$.

In general, based on the relatively consistent ratio of all bark beetles to all predators, changes in annual abundances of predators and bark beetles followed similar patterns within each elevation band and across all bands pooled (Table 5). Within the low- and highelevation bands and across all bands pooled, there were no significant differences in this ratio $(P>0.05)$. The ratio for the mid-elevation band was significantly higher in 2005 and 2006 as a result of comparatively fewer predators being trapped than their prey in these 2 years $(P<0.05)$.

\section{Lure Preference}

Trap catches of all 3 predators varied among lures (Fig. 5). Temnochila chlorodia was most attracted to the I. pini and I. lecontei lures $(P<0.001)$; trap catches with these 2 lures accounted for $36.9 \%$ and $48.1 \%$ of the 12,891 T. chlorodia collected. Enoclerus sphegeus was most attracted to the I. lecontei lure, which captured $90.0 \%$ of the 4278 E. sphegeus $(P<$ 0.001). Enoclerus lecontei was most attracted to the I. pini lure, which captured $74.5 \%$ of the 940 beetles collected $(P<0.001)$. All 3 predators were least attracted to the $D$. brevicomis 


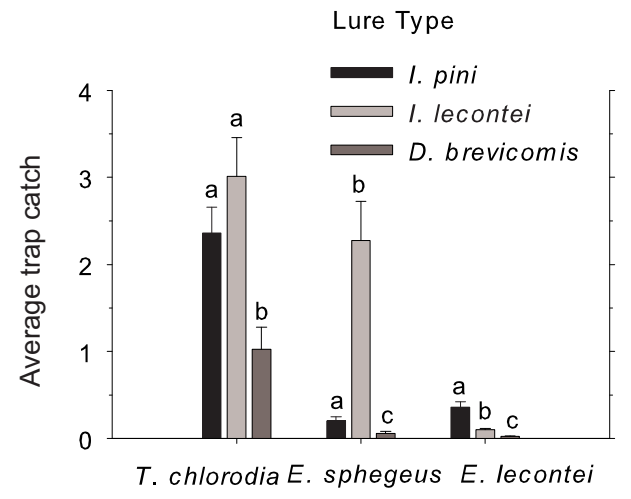

Fig. 5. Lure preferences of 3 bark beetle predators collected in funnel traps baited with a semiochemical lure combination targeting either I. pini (ipsdienol +03/-97, lanierone), I. lecontei (ispsenol +50/-50, ipsdienol $+50 /-50$, cis-verbenol $+17 /-83$ ), or D. brevicomis (frontalin, exobrevicomin, myrcene) in north central Arizona, 2005-2006. Data are presented as mean weekly trap catch per site pooled by years. Error bars represent one standard error. Means followed by same letter within a predator category are not significantly different $(\mathrm{P}>0.05$, MRPP).

lure, which accounted for $<15 \%$ of the total trap catches for each predator.

\section{Discussion}

All 3 predators, T. chlorodia, E. sphegeus, and $E$. lecontei, were collected across the entire elevation range (1600-2651 m) of this study; however, like their bark beetle prey (Williams et al. 2008), predators varied with elevation in both abundance and flight activity. In general, flight initiation of predators closely followed flight initiation of bark beetles in the spring. However, predator flight terminated much earlier than bark beetle flight, contributing to high prey-predator capture ratios in the fall. Seasonal differences in flight activity between prey and predators were also observed with $I$. pini and predators in Wisconsin (Raffa 1991, Aukema et al. 2000a, 2000b) and California (Dahlsten et al. 2003, 2004). Seasonal differences in flight activity suggest that certain bark beetle species may be afforded some temporal escape from predators in the fall.

Temnochila chlorodia, the most abundant predator collected in this study, was most commonly found below $2230 \mathrm{~m}$, which corresponds with the elevational distribution of its major prey: I. pini, I. lecontei, and D. brevicomis (Williams et al. 2008). The high number of $T$. chlorodia captured in the low-elevation band may also be influenced by pinyon ips $I$. confusus (LeConte) serving as an additional food source at lower elevations. High trap catches of T. chlorodia were observed in pheromone-baited traps targeting I. confusus in pinyon-juniper woodlands (elevation 1270-1441 $\mathrm{m}$ ) in north central Arizona (DeGomez unpublished data); however, E. lecontei was caught more frequently than $T$. chlorodia in similarly baited traps in southern Arizona (Cane et al. 1990). Hofstetter et al. (2008) also reported $T$. chlorodia to be the most abundant bark beetle predator collected in a recent study examining lure preferences of $D$. brevicomis and $D$. frontalis and associated insects at mid-elevations in north central Arizona. The observation that $T$. chlorodia flight initiation usually followed flight initiation of its bark beetle prey by 1-3 weeks also corresponds with findings by Gaylord et al. (2006) near Flagstaff, Arizona. This pattern is likely a reflection of the higher temperature threshold required for flight initiation of $T$. chlorodia than for flight initiation of most of its bark beetle prey (Gaylord et al. 2008). Peak flight activity during June and July matches previous reports on flight seasonality of $T$. chlorodia (Stephen and Dahlsten 1976, Gara et al. 1999, Dahlsten et al. 2003, Fettig and Dabney 2006, Gaylord et al. 2006). A coincidence of high trap catches of T. chlorodia and peak flight activity of D. brevicomis, I. pini, and I. lecontei corresponds with observations made by Gaylord et al. (2006). Additionally, T. chlorodia has exhibited close synchrony with the arrival of I. pini to I. pini-infested logs (Raffa and Dahlsten 1995) and with the mass arrival of $D$. brevicomis to ponderosa pine trees (Stephen and Dahlsten 1976).

Enoclerus sphegeus was most commonly collected at higher elevations, where bark beetle prey such as D. adjunctus (Blackman 1931, Chansler 1967, Massey et al. 1977), D. ponderosae (Boving and Champlain 1920, Blackman 1931, Amman 1970, Furniss and Carolin 1977), and D. pseudotsugae (Kline and Rudinsky 1964, Cowan and Nagel 1965, Furniss and Carolin 1977) are also commonly found (Blackman 1931, USDA Forest Service 2003-2004, Williams et al. 2008). Abundance of this predator decreased with decreasing elevation. Our observations on seasonal flight activity of E. sphegeus are consistent with 
previous reports in Arizona (Blackman 1931, Ostmark 1966), New Mexico (Chansler 1967), and Montana (Gara et al. 1999). Flight initiation coincided with the minor spring flight of D. adjunctus, and peak trap catches overlapped summer flight activity of I. pini and D. brevicomis. The high abundance of E. sphegeus captured from June to August in the highelevation band corresponds with peak flight activity of D. pseudotsugae (Furniss and Carolin 1977, Wood 1982, Schmitz and Gibson 1996), indicating this bark beetle may serve as an additional food source during the summer months. Flight activity of E. sphegeus diminished before the major flight of $D$. adjunctus occurred in October, suggesting that $D$. adjunctus may be afforded some temporal escape from one of its primary predators during the fall.

Enoclerus lecontei is recognized as a major predator of bark beetles, specifically of $D$. brevicomis (Person 1940, Berryman 1970, Stephen and Dahlsten 1976), but it was collected in relatively low numbers in our study. Low E. leconte $i$ trap catches were also reported by Fettig and Dabney (2006) in a study of predators collected in D. brevicomis-pheromone-baited traps in northern California. The observation that $E$. lecontei peak flight activity occurred in July and August is consistent with other reports in Arizona (Ostmark 1966) and California (Stephen and Dahlsten 1976) but contrasts with reports of spring peaks in California and Montana (Person 1940, Berryman 1970, Gara et al. 1999). A coincidence of high trap catches of E. lecontei and summer flight activity of I. pini and D. brevicomis corresponds with previous reports that this predator exhibited close synchrony with the arrival of I. pini to I. pini-infested logs (Raffa and Dahlsten 1995) and with the mass arrival of $D$. brevicomis to ponderosa pine trees (Stephen and Dahlsten 1976).

There are no documented predators of $D$. frontalis west of Texas. Temnochila virescens (Fabricius) and Thanasimus dubius (Fabricius) are known associated predators of $D$. frontalis in eastern Texas (Moser et al. 1971) but were not collected in this study. Our observation that high trap catches of $T$. chlorodia and $E$. sphegeus coincided with spring and summer flight activity of $D$. frontalis corresponds with previous findings (Gaylord et al. 2006) near Flagstaff, Arizona. While these results suggest potential predator-prey associations, further investigation is needed to confirm these relationships.

Our results suggest that resource partitioning is occurring on an elevational scale. While all 3 predators share common food sources, their elevational distribution differs. Temnochila chlorodia was most abundant in lowand mid-elevation bands, where I. pini, I. lecontei, and D. brevicomis are common. Enoclerus sphegeus was most profuse at high elevations, where $I$. pini, D. adjunctus, and $D$. pseudotsugae are common. Enoclerus lecontei was found across all elevations in low numbers. Although we are not aware of resource partitioning taking place across elevation gradients for other prey-predator systems, resource partitioning of prey (I. pini) among E. sphegeus, E. lecontei, and T. chlorodia has been found to occur temporally (Gara et al. 1999). The authors reported that the densest flight of each predator coincided with a different peak in I. pini flight in southeastern Montana. Resource partitioning among predators on a temporal scale was not observed in our study; predator flight activity, including the highest trap catches of the season, typically overlapped. Partitioning of prey by predators may be mediated by their differential response to bark beetle pheromones (Raffa et al. 2007).

This study was not explicitly designed to test for lure preference of predators, and results should be interpreted with caution; however, our results suggest the $D$. brevicomis lure was least attractive to all 3 predators. A lack of response by E. sphegeus and E. leconte $i$ to the $D$. brevicomis lure has been reported in previous research (Zhou et al. 2001, Fettig and Dabney 2006, Gaylord et al. 2006, Hofstetter et al. 2008). In contrast, exo-brevicomin, a component of the $D$. brevicomis lure and other Dendroctonus species lures, is known to be highly attractive to T. chlorodia (Pitman and Vité 1971, Bedard et al. 1980, Byers 1988, Zhou et al. 2001, Hofstetter et al. 2008). Nevertheless, our results correspond with a recent study near Flagstaff, Arizona, which also found T. chlorodia to be more attracted to the I. pini lure than the D. brevicomis lure (Gaylord et al. 2006). This may suggest that $T$. chlorodia exhibits geographic differences in its attraction to semiochemicals. Preference by E. sphegeus for the I. lecontei lure corresponds with its reported attraction to a combination of ipsenol and cis-verbenol (Miller et al. 1991). Similarly, 
preference by E. lecontei for the I. pini lure is consistent with its reported attraction in western North America to a combination of ipsdienol and lanierone (Seybold et al. 1992, Miller et al. 1997, Dahlsten et al. 2003, 2004, Miller et al. 2005). It is interesting to note that E. sphegeus, which is most abundant at high elevations in our study, is most attracted to the I. lecontei lure; however, I. lecontei is most commonly found at low- to mid-elevations. In contrast, $E$. lecontei, which has no consistent trend in abundance with respect to elevation, shows preference for the I. pini lure. Ips pini was previously found to exhibit no trend in abundance by elevation (Williams et al. 2008). Similarly, T. chlorodia is most abundant at low elevations and shows preference for the I. lecontei lure, coinciding with where I. lecontei is most prevalent. Thus, E. sphegeus seems to be an anomaly in Arizona; it is attracted to a semiochemical lure produced by a prey species that is relatively uncommon in the habitat where E. sphegeus is most abundant.

Our results have implications for semiochemical management of bark beetles. Lateseason pheromone trapping would be least detrimental to the natural enemy complex; fewer predators would be trapped and, therefore, they could have a greater impact on bark beetle populations. Our results also provide insight into how flight seasonality of predators relates to the flight seasonality of several bark beetle species. Prey-predator ratios have been used for predicting bark beetle population trends and forecasting infestations (Billings 1988). Additional research to evaluate the impact of each predator, or their combined effects, on population dynamics of bark beetle species is a necessary step toward developing similar predictive models in this region. Based on the relatively consistent ratio of all prey to all predators, combined abundance of the 3 predators examined in our study seemed to track abundance of the bark beetle complex. The exception was for the mid-elevation band, where comparatively fewer predators were trapped in 2005 and 2006 than their prey, resulting in significantly higher ratios for these 2 years.

To our knowledge, this is the first study examining abundance of bark beetle predators and their flight seasonality across an elevational gradient using pheromone-baited traps. While pheromone traps are a widely used tool for monitoring bark beetle abundance and flight seasonality, several studies have demonstrated disparate responses among bark beetles and their predators to semiochemical lures (Raffa and Klepzig 1989, Herms et al. 1991, Raffa 1991, Seybold et al. 1992, Aukema et al. 2000a, 2000b, Dahlsten et al. 2003, 2004). These differences can influence the interpretation of pheromone-trap results such as estimations of relative abundance, flight seasonality, and preypredator ratios. Further investigation is needed to determine whether bark beetles and their predators exhibit chemical, seasonal, or geographic differences in their attraction to synthetic pheromones in this region.

\section{ACKNOWLEDGMENTS}

We thank Chris Hayes, Andrew Miller, Beverly Loomis, T. Seth Davis, Amanda Garcia, Vernon Bunker, Grace Hancock, Ken Baumgartner, Eric Osborne, Wesley Winslow, Mayra Moreno, Laine Smith, Kate Murray, Michelle Schaffer, Andrew Somerville, Juliana Suby, and Marc Trenam for field and lab assistance. Statistical advice provided by Rudy King is greatly appreciated. We thank the Coconino, Kaibab, and Tonto National Forests for permitting our work on public lands. This study was supported by the 2004 Forest Service, Forest Health Protection, Western Bark Beetle Research Initiative and Agreement 03-JV11221605-237 between the Rocky Mountain Research Station, Northern Arizona University, and the University of Arizona, and by the National Fire Plan research project 01 .RMS.B.4.

\section{Literature Cited}

Amman, G.D. 1970. Prey consumption and variations in larval biology of Enoclerus sphegeus (Coleoptera: Cleridae). Canandian Entomologist 102:1374-1379.

Aukema, B.H., M.K. Clayton, and K.F. Raffa. 2005. Modeling flight activity and population dynamics of the pine engraver, Ips pini, in the Great Lakes region: effects of weather and predators over short time scales. Population Ecology 47:61-69.

Aukema, B.H, D.L. Dahlsten, and K.F. Raffa. 2000a. Improved population monitoring of bark beetles and predators by incorporating disparate behavioral responses to semiochemicals. Environmental Entomology 29:618-629.

2000b. Exploiting behavioral disparities among predators and prey to selectively remove pests: maximizing the ratio of bark beetles to predators removed during semiochemically based trap-out. Environmental Entomology 29:618-629. 
Bedard, W.D., D.L. Wood, P.E. Tilden, K.Q. Lindahl, JR., R.M. Silverstein, and J.O. Rodin. 1980. Field responses of the western pine beetle and one of its predators to host- and beetle-produced compounds. Journal of Chemical Ecology 6:625-641.

Berryman, A.A. 1970. Evaluation of insect predators of the western pine beetle. Pages 102-112 in R.W. Stark and D.L. Dahlsten, editors, Studies on the population dynamics of the western pine beetle, Dendroctonus brevicomis Leconte (Coleoptera: Scolytidae). University of California, Division of Agricultural Sciences.

BILLINGS, R.F. 1988. Forecasting southern pine beetle infestation trends with pheromone traps. Pages 295-306 in T.L. Payne and H. Saarenmaa, editors, Proceedings of the Integrated Control of Scolytid Bark Beetles Symposium. Virginia Polytechnical Institute and State University, Blacksburg.

Blackman, M.W. 1931. The Black Hills beetle (Dendroctonus ponderosae Hopkins). Technical Publication No. 36, New York State College of Forestry, Syracuse University, Syracuse, NY.

Boving, A.G., And A.B. Champlain. 1920. Larvae of North American beetles of the family Cleridae. Proceedings of the U.S. National Museum 57:575-649.

Byers, J.A. 1988. Novel diffusion-dilution method for release of semiochemicals: testing pheromone component ratios on western pine beetle. Journal of Chemical Ecology 14:199-212.

Cane, J.H., L.D. Merrill, and D.L. Wood. 1990. Attraction of pinyon pine bark beetle, Ips hoppingi, to conspecific and I. confusus pheromones (Coleoptera: Scolytidae). Journal of Chemical Ecology 16: 2791-2798.

Chansler, J.F. 1967. Biology and life history of Dendroctonus adjunctus (Coleoptera: Scolytidae). Annals of the Entomological Society of America 60:760-767.

Cowan, B.D., AND W.P. NagEL. 1965. Predators of the Douglas-fir beetle in western Oregon. Technical Bulletin 86, Oregon Agricultural Experiment Station.

Dahlsten, D.L., D.L. Six, N. Erbilgin, K.F. RafFa, A.B. LAWSON, AND D.L. Rowney. 2003. Attraction of Ips pini (Coleoptera: Scolytidae) and its predators to various enantiomeric ratios of Ipsdienol and Lanierone in California: implications for the augmentation and conservation of natural enemies. Environmental Entomology 32:1115-1122.

Dahlsten, D.L., D.L. Six, D.L. Rowney, A.B. Lawson, N. ERBILGIN, AND K.F. RAFFA. 2004. Attraction of Ips pini (Coleoptera: Scolytinae) and its predators to natural attractants and synthetic semiochemicals in northern California: implications for population monitoring. Environmental Entomology 33: 1554-1561.

Dahms, C.W., AND B.W. Geils. 1997. An assessment of forest ecosystem health in the Southwest. General Technical Report RM-GTR-295, USDA Forest Service, Rocky Mountain Forest and Range Experiment Station, Fort Collins, CO.

DeMars, C.J., Jr., and B.H. Roettgering. 1982. Western pine beetle. Forest Insect and Disease Leaflet 1, USDA Forest Service, Washington, DC.

Erbilgin, N., E.V. Nordheim, B.H. Aukema, and K.F. RAFFA. 2002. Population dynamics of Ips pini and Ips grandicollis in red pine plantations in Wisconsin: within- and between-year associations with predators, competitors, and habitat quality. Environmental Entomology 31:1043-1051.
ERbiLgin, N., AND K.F. RAFFA. 2001. Kairomonal range of generalist predators in specialized habitats: responses to multiple phloeophagous species emitting pheromones vs. host odors. Entomologia Experimentalis et Appicata 99:205-210.

Eyre, F.H. 1980. Forest cover types of the United States and Canada. Society of American Foresters, Washington, DC.

Fettig, C.J., AND C.P. Dabney. 2006. Seasonal abundance of Temnochila chlorodia (Mannerheim) (Coleoptera: Trogositidae) collected in western pine beetle pheromone baited traps in northern California. Journal of Entomological Science 41:75-83.

Furniss, R.L., and V.M. Carolin. 1977. Western forest insects. Forest Service, Washington, DC.

Gara, R.I., D.R. Millegan, and K.E. Gibson. 1999. Integrated pest management of Ips pini (Coleoptera: Scolytidae) populations in south-eastern Montana. Journal of Applied Entomology 123:529-534.

GaYlord, M.L., T.E. KolB, K.F. WaLlin, AND M.R. WaGNER. 2006. Seasonality and lure preference of bark beetles (Curculionidae: Scolytinae) and associates in a northern Arizona ponderosa pine forest. Environmental Entomology 35:37-47.

Gaylord, M.L., K.K. Williams, R.W. Hofstetter, J.D. McMillin, T.E. DeGomez, and M.R. Wagner. 2008. Influence of temperature on spring flight initiation for southwestern ponderosa pine bark beetles (Coleoptera: Curculionidae, Scolytinae). Environmental Entomology 37:57-69.

Hayes, C., T.E. DeGomez, K.M. Clancy, K. Williams, J.D. MCMillin, AND J.A. ANHOLD. 2008. Evaluation of funnel traps for characterizing the bark beetle (Coleoptera: Curculionidae, Scolytinae) communities in ponderosa pine forests of north-central Arizona. Journal of Economic Entomology 101: 1253-1265.

Herms, D.A., R.A. HaAcK, AND B.D. Ayres. 1991. Variation in semiochemical-mediated prey-predator interaction: Ips pini (Scolytidae) and Thanasimus dubius (Cleridae). Journal of Chemical Ecology 17: 515-524.

Hofstetter, R.W., Z. Chen, M.L. Gaylord, J.D. MCMilLin, AND M.R. WAGNER. 2008. Synergistic effects of $\alpha$-pinene and exo-brevicomin on pine bark beetles and associated insects in Arizona. Journal of Applied Entomology 132:387-397.

Kline, L.N., AND J.A. Rudinsky. 1964. Predators and parasites of the Douglas-fir beetle: description and identification of the immature stages. Technical Bulletin 79, Oregon Agricultural Experiment Station.

Lindgren, B.S. 1983. A multiple funnel trap for scolytid beetles (Coleoptera). Canadian Entomologist 115: 299-302.

Massey, C.L., D.D. Lucht, and J.M. Schmid. 1977. Roundheaded pine beetle. Forest and Insect Disease Leaflet 155. USDA Forest Service, Washington, DC.

MielKe, P.W., JR., and K.J. Berry. 2001. Permutation methods: a distance function approach. SpringerVerlag, New York.

Miller, D.R., ANd J.H. Borden. 1990. $\alpha$-phellandrene: kairomones for pine engraver, Ips pini (Say) (Coleoptera: Scolytidae). Journal of Chemical Ecology 16: 2519-2531.

Miller, D.R., J.H. Borden, G.G.S. King, and K.N. SLESSOR. 1991. Ipsenol: an aggregation pheromone for Ips latidens (Leconte) (Coleoptera: Scolytidae). Journal of Chemical Ecology 17:1517-1527. 
Miller, D.R., J.H. Borden, ANd B.S. Lindgren. 2005. Dose-dependent pheromone responses of Ips pini, Orthotomicus latidens (Coleoptera: Scolytidae), and associates in stands of lodgepole pine. Environmental Entomology 34:591-597.

Miller, D.R., K.E. Gibson, K.F. RafFa, S.J. Seybold, S.A. TEale, and D.L. Wood. 1997. Geographic variation in response of pine engraver, Ips pini, and associated species to pheromone, lanierone. Journal of Chemical Ecology 23:2013-2031.

Miller, J.M., AND F.P. KEEN. 1960. Biology and control of the western pine beetle: a summary of the first fifty years of research. Miscellaneous Publication No. 800, USDA Forest Service, Pacific Southwest Forest and Range Experiment Station, Washington, DC.

Moir, W.H., B. Geils, M.A. Benoit, and D. Scurlock. 1997. Ecology of southwestern ponderosa pine forests. General Technical Report RM-GTR-292 USDA Forest Service, Rocky Mountain Forest and Range Experiment Station, Fort Collins, CO.

Moser, J.C., R.C. Thatcher, and L.S. Pickard. 1971. Relative abundance of southern pine beetle associates in east Texas. Annals of the Entomological Society of America 64:72-77.

Ostmark, H.E. 1966. The life history, habits and control of the Arizona five-spined Ips, Ips lecontei Swaine (Coleoptera: Scolytidae). Doctoral dissertation, University of Florida, Gainesville, FL.

Person, H.L. 1940. The clerid Thanasimus lecontei (Wolc.) as a factor in the control of the western pine beetle. Journal of Forestry 38:390-396.

Pitman, G.B., AND J.P. Vité. 1971. Predator-prey response to western pine beetle attractants. Journal of Economic Entomology 64:403-404.

RAFFA, K.F. 1991. Temporal and spatial disparities among bark beetles, predators and associates responding to synthetic bark beetle pheromones: Ips pini (Coleoptera: Scolytidae) in Wisconsin. Environmental Entomology 20:1665-1679.

Raffa, K.F., and D.L. Dahlsten. 1995. Differential responses among natural enemies and prey to bark beetle pheromones. Oecologia 102:17-23.

RafFa, K.F., K.R. Hobson, S. LaFontaine, and B.H. Aukema. 2007. Can chemical communication be cryptic? Adaptations by herbivores to natural enemies exploiting prey semiochemistry. Oecologia 153: $1009-1019$

RAFFA, K.F., AND K.D. KLePZiG. 1989. Chiral escape of bark beetles from predators responding to a bark beetle pheromone. Oecologia 80:566-569.

Reeve, J.D. 1997. Predation and bark beetle dynamics. Oecologia 112:48-54.

Reeve, J.D., AND P. Turchin. 2002. Evidence for predator-prey cycles in a bark beetle. Pages 92-108 in A.A. Berryman, editor, Population cycles: the case for trophic interactions. Oxford University Press, New York.

SÁNCheZ-MarTínEZ, G., AND M.R. Wagner. 2002. Bark beetle community structure in four ponderosa pine stand conditions in northern Arizona. Forest Ecology and Management 170:145-160.

SchmitZ, R.F., AND K.E. Gibson. 1996. Douglas-fir beetle. Forest and Insect Disease Leaflet 5, USDA Forest Service, Washington, DC.
Seybold, S.J., S.A. Teale, D.L. Wood, A. Zhang, F.X. Webster, K.Q. Lindahl, JR., and I. Kubo. 1992. The role of lanierone in the chemical ecology of Ips pini (Coleoptera: Scolytidae) in California. Journal of Chemical Ecology 18:2305-2329.

Stephen, F.M., And D.L. Dahlsten. 1976. The arrival sequence of the arthropod complex following attack by Dendroctonus brevicomis (Coleoptera: Scolytidae) in ponderosa pine. Canadian Entomologist 108: 283-304.

Struble, G.R. 1942. Biology of two native coleopterous predators of the mountain pine beetle in sugar pine. Pan-Pacific Entomologist 18:97-107.

Turchin, P., A.D. Taylor, and J.D. ReEve. 1999. Dynamical role of predators in population cycles of a forest insect: an experimental test. Science 285:1068-1071.

USDA Forest Service. 2002a. Generalized vegetation communities on the Tonto National Forest. Vector digital data. USDA Forest Service, Southwestern Region, Albuquerque, NM. Available from: http:// www.fs.fed.us/r3/wui/maps/map_index.html

2002b. Generalized vegetation communities on the Coconino National Forest. Vector digital data. USDA Forest Service, Southwestern Region, Albuquerque, NM. Available from: http://www.fs.fed.us /r3/wui/maps/map_index.html

.2002c. Generalized vegetation communities on the Kaibab National Forest. Vector digital data. USDA Forest Service, Southwestern Region, Albuquerque, NM. Available from: http://www.fs.fed.us/r3/wui/maps /map_index.html

2003-2004. Forest insect and disease conditions in the Southwestern Region. USDA Forest Service, Southwestern Region, Forestry and Forest Health, Albuquerque, NM. Available from: http://www.fs.fed .us/r3/publications/.

Williams K.K., J.D. McMillin, T.E. DeGomez, K.M. Clancy, and A. Miller. 2008. Influence of elevation on bark beetle (Coleoptera: Curculionidae, Scolytinae) community structure and flight periodicity in ponderosa pine forests of Arizona. Environmental Entomology 37:94-109.

Wood, D.L., L.E. Browne, W.D. Bedard, P.E. Tilden, R.M. Silverstein, and J.O. Rodin. 1968. Response of Ips confusus to synthetic sex pheromones in nature. Science 159:1373-1374.

WooD, S.L. 1982. The bark and ambrosia beetles of North and Central America (Coleoptera: Scolytidae), a taxonomic monograph. Great Basin Naturalist Memoirs 6. Brigham Young University, Provo, UT.

Zhou, J., D.W. Ross, ANd C.G. Niwa. 2001. Kairomonal response of Thanasimus undatulus, Enoclerus sphegeus (Coleoptera: Cleridae), and Temnochila chlorodia (Coleoptera: Trogositidae) to bark beetle semiochemicals in eastern Oregon. Environmental Entomology 30:993-998.

Zimmerman, G.M., H. Goetz, and P.W. Mielke, Jr. 1985. Use of an improved statistical method for group comparisons to study effects of prairie fire. Ecology 66:606-611.

Received 10 July 2008

Accepted 27 January 2009 